Article

\title{
The Impact of Education on Household Income in Rural Vietnam
}

\author{
Hung Van Vu \\ Faculty of Political Theory, Thuongmai University, Hanoi 100000, Vietnam; hungvvu@tmu.edu.vn
}

Received: 9 October 2019; Accepted: 11 February 2020; Published: 18 February 2020

\begin{abstract}
Using data from the 2018 Vietnam Household Living Standard Survey, our study investigates the impact of education on household income in rural Vietnam. Both mean and quantile regression analyses were employed to analyze the impact of education. We found that education has a positive effect on the household income after controlling for various factors in the models. However, quantile regression analysis reveals that the effect of schooling years increases with quantiles, suggesting that education bring higher returns for richer households. We also found that households with the heads having higher qualifications or vocational education tend to earn higher income levels. Combined together, these findings imply that while education was found to increase household income, it increases income inequality in rural Vietnam. Our research findings suggest that improving the access of poor households to better education is expected to increase their income and reduce inequality in rural Vietnam.
\end{abstract}

Keywords: education; household income; inequality; quantile regression; rural Vietnam

JEL Classification: I21; I24; I25; I26

\section{Introduction}

Vietnam's socio-economic development has generally been considered a success story. Over the past three decades, the country moved from one of the poorest countries in the world to a lower-middle income country, with per capita income of 1130 per annual by the end of 2010 (Tien 2014). Education has played as a major factor in the country's development attainment. Not only offering a pathway out of poverty, education also has provided the workforce with vital skills to convert a farming-based economy into an industrial-based one. This success stems from the fact that education has been considered as a top-priority policy in Vietnam (Tien 2014). The country has attained great achievements in universalizing primary and lower secondary education. Also, student loans have been also given for tertiary education.

Numerous studies have devoted to the analysis of the impact of education on household income (Nguyen and Tran 2018; Tran et al. 2018) or wage premiums (Doan et al. 2018a, 2018b) in Vietnam. The studies have often used a mean regression approach (e.g., ordinary least squares, random or fixed effect estimators) which only estimate the mean response of household income or wages dependent on the independent variables. Thus, this approach only revealed the average relationship between education and household income (Koenker 2005). However, a quantile regression enables researchers to examine the relationship at different points in the conditional distribution of income (Koenker 2005). In other words, using quantile analysis, we can answer the question whether the impact of education is heterogeneous across all considered percentiles of income distribution (Koenker and Hallock 2001).

Measuring the contribution of education to household income is much of importance to policy makers (Tran et al. 2018). The role of education in household income and poverty reduction has been well established in the literature. Most studies confirm that education helps households improve their 
economic welfare (Rigg 2006; Tran et al. 2018). In addition, the quantile regression analysis in most countries shows that education offer positive returns for all income groups (Sakellariou et al. 2006). However, education can have different impacts on different percentiles of income distribution. Evidence shows that while the positive impact of education tends to be larger for richer households in Spain (Alves 2012), it was found to bring higher returns for poorer rural housholds in the Philipines (Pede et al. 2012). The findings suggest that education tends to increase inequality in Spain but reduce inquality in the Philipines.

In Vietnam, using a mean regression approach, a number of studies has analyzed the role of education in household income, mostly focusing on some specific regions such as the Northwest (Nguyen and Tran 2018) or North central regions (Nguyen and Tran 2018). Also, Tran et al. (2019) have examined the impact of education on wage incomes, using both mean and quantile approaches. Their study focuses on wage incomes, using the sample of wage earners only. To the best of our knowledge, no study used a quantile regression to analyze the heterogeneous impacts of education on household income in rural Vietnam. It is much of importance to investigate the heterogeneous impacts on household income across various percentiles of income distribution, not only at the mean. Thus, a quantile regression analysis would bring better information for policy-makers regarding the contribution of education to different income groups in rural Vietnam. It is therefore necessary to reexamine the role of education in household income using a quantile regression analysis with the updated data. The gap in the literature inspired us to conduct this research.

In our research, data were taken from Vietnam Household Living Standards Survey in 2018. In the study, education is measured by the heads number of formal schooling years, vocational education, and the highest education qualifications. We found that education has a positive effect (or return) on household income, after controlling for other factors in the models. Also, the effect of schooling years is quite homogenous across all the considered percentiles, suggesting that education bring the same return to all income groups. We also found that households with the head having higher qualifications or vocational education tend to obtain higher income levels. Combined together, these findings imply that education bring positive effects on income and do not increase inequality in rural Vietnam.

\section{Data and Methods}

\subsection{Data}

Our research utilizes data from the 2018 Vietnam Household Living Standard Survey (VHLSS). The survey was conducted by the General Statistics Office of Vietnam (GSO) with technical help from the World Bank. The survey represents the national and regional levels. We used income data from the sample of rural households, including 32,000 households. The VHLSS contained rich information about demographic characteristics, employment and economic sources, education, health, housing, durable assets, and land. In particular, the data included detailed information about the education levels of household members, including general, professional and vocational education.

\subsection{Methods}

Both descriptive statistics and regression analysis were utilized for our research objectives. First, the household sample was clustered into income terciles, namely low, middle, and high income groups. Then, we compared the household characteristics across income groups. Regression analyses using both OLS Equation (1) and quantile regression Equation (2) were employed to examine the impact of education on household income, controlling for other factors in the models. In Equation (1), $\operatorname{LnY} Y_{i}$ is the $\log$ per capita income of household $i, X_{i}$ is a vector of household characteristics, such as household size, dependency ratio and age, gender and ethnicity of the household heads; $E_{i}$ is the education level of household heads; $L_{i}$ represents various kinds of lands; $R_{i j}$ is the dummy variable of regions. $\beta_{i}$ is the parameter that needs to be estimated, and $\epsilon_{i}$ and $u_{i}$ are error terms. Equation (2) includes the same explanatory variables as those in Equation (1). However, we do not transform household income into 
logarithm in Equation (2). As noted by Lingxin and Daniel (2007), it would be a mistake to use the log income to infer conclusions about income distribution (despite that it is normally used in practice). Also, using the income model allows us to measure the absolute impact of education on income.

$$
\begin{aligned}
& \operatorname{LnY}_{i}=\beta_{o}+\beta_{1} X_{i}+\beta_{2} E_{i}+\beta_{3} L_{i}+\beta_{4} R_{i}+\epsilon_{i} \\
& \mathrm{QY}_{i}=\beta_{o}+\beta_{1} X_{i}+\beta_{2} E_{i}+\beta_{3} L_{i}+\beta_{4} R_{i}+u_{i}
\end{aligned}
$$

As already mentioned, the quantile regression approach has a merit of allowing parameter varying across quantiles of the income distribution. This approach enables researchers to examine whether the education increases income inequality (Alves 2012). If the effect of education increases with quantiles, it tends to benefit the rich more than the poor, which suggests that education increases income inequality (both absolute and relative inequality). By contrast, education reduces inequality if its effect tends to be larger for those at lower income percentiles (Fasih et al. 2012).

In our study, education of households was measured by the education levels of household heads. This is because empirical evidence (Alves 2012; Revenga et al. 2002; Tran et al. 2018) shows that the social and economic status of a household is often dependent on the characteristics of its household head (e.g., education or gender). In addition, using the education of household heads as an explanatory variable instead of all household members helps avoid "reverse causality" (Revenga et al. 2002). This is because household heads are adults who currently work and do not go to school.

\section{Results and Discussion}

\subsection{Descriptive Analysis of Rural Households}

As seen in Table 1, three household groups or income terciles were created using the "xtile" STATA command. On average, each rural household earned about 2.96 million Vietnam Dong (VND) per person per month in 2018. The corresponding figure for low, middle, and high income groups is about 1.10, 2.42, and 3.35 million VND. The results show that the number of formal schooling years tends to be higher for higher income groups. Also, the number of household heads without formal education is also much higher for low income households (nearly 30\%) than that of those in the middle and high income groups (about $20 \%$ and $12 \%$, respectively). The proportion of household heads with higher qualifications are also associated with higher income levels. Table 1 indicates that the share of household heads with vocational is quite low among rural households. However, this share is greater for richer households. The data in Table 1 suggest that education is highly positively associated with income levels.

Table 2 compares the differences in characteristics across household groups. There is a large difference in ethnicity across groups, with a much higher households belonging to the Kinh/Hoa group for middle and high income than that for those in the ethnic minority population. However, there is little differences in other demographic features across groups. The participation rates in wage or non-farm self-employment are also lower for poor households than those for middle and high income households. The share of households having a membership of farmer association is higher for the low income group, while the share of households with a communist party membership is higher for the middle and high income group. On average, the low income group holds more forestland and annual cropland than did the middle and high income group. However, the latter own more perennial cropland than the former. Overall, the results suggest that some types of household characteristics and assets are linked with income status. 
Table 1. Household heads' education by income group.

\begin{tabular}{lcccc}
\hline \multicolumn{1}{c}{ Education } & Low Income & $\begin{array}{l}\text { Middle } \\
\text { Income }\end{array}$ & High Income & Whole Sample \\
\hline Schooling years & 6.469 & 7.644 & 9.045 & 7.780 \\
(number years of formal & $(3.308)$ & $(3.545)$ & $(3.770)$ & $(3.707)$ \\
schooling) & $29.70 \%$ & $19.60 \%$ & $12.00 \%$ & $20.00 \%$ \\
No education & $33.11 \%$ & $30.76 \%$ & $24.57 \%$ & $29.29 \%$ \\
Primary education & $27.60 \%$ & $31.64 \%$ & $32.03 \%$ & $30.55 \%$ \\
Lower secondary education & $7.65 \%$ & $11.16 \%$ & $15.65 \%$ & $11.67 \%$ \\
Upper secondary education & $0.76 \%$ & $2.39 \%$ & $4.61 \%$ & $2.68 \%$ \\
College & $1.17 \%$ & $4.45 \%$ & $11.14 \%$ & $5.81 \%$ \\
University and higher & $1.29 \%$ & $3.23 \%$ & $5.07 \%$ & $3.29 \%$ \\
Primary vocational & $0.63 \%$ & $1.78 \%$ & $2.67 \%$ & $1.75 \%$ \\
Secondary apprentice & $0.83 \%$ & $2.30 \%$ & $4.23 \%$ & $2.53 \%$ \\
Professional secondary & $0.06 \%$ & $0.24 \%$ & $0.48 \%$ & $0.27 \%$ \\
College vocational & 1102.833 & 2423.552 & 5352.178 & 2959.065 \\
Per capita income & $(423.925)$ & $(414.589)$ & $(3952.328)$ & $(2910.978)$ \\
(Sd) & 10,697 & 10,702 & 10,692 & 32,091 \\
Observations & & & & \\
\hline
\end{tabular}

1 USD is equal about 23 thousand Vietnam Dong (VND) in 2018. Source: authors' own calculation from the 2018 VHLSS.

Table 2. Household characteristics by income group.

\begin{tabular}{|c|c|c|c|c|c|c|c|c|}
\hline \multirow{2}{*}{ Characteristics } & \multicolumn{2}{|c|}{ Low Income } & \multicolumn{2}{|c|}{ Middle Income } & \multicolumn{2}{|c|}{ High Income } & \multicolumn{2}{|c|}{ Whole Sample } \\
\hline & Mean/Share & SD & Mean/Share & SD & Mean/Share & SD & Mean/Share & SD \\
\hline Ethnicity (1 = major; o = minor $)$ & $54 \%$ & & $86 \%$ & & $94 \%$ & & $78 \%$ & $41 \%$ \\
\hline Age (years) & 52.01 & 15.97 & 52.65 & 13.50 & 51.69 & 11.71 & 52.12 & 13.84 \\
\hline $\begin{array}{l}\text { Marital status }(1=\text { married, } 0= \\
\text { otherwise })\end{array}$ & $78 \%$ & & $81 \%$ & & $83 \%$ & & $81 \%$ & \\
\hline Gender ( $1=$ male; 0 = female $)$ & $77 \%$ & & $78 \%$ & & $79 \%$ & & $78 \%$ & \\
\hline Dependency ratio $^{a}$ & $48 \%$ & & $41 \%$ & & $31 \%$ & & $40 \%$ & \\
\hline Household size (total members) & 3.98 & 1.85 & 3.79 & 1.55 & 3.45 & 1.47 & 3.74 & 1.65 \\
\hline Wage employment $(1=$ yes; $0=$ not $)$ & $32 \%$ & & $41 \%$ & & $41 \%$ & & $38 \%$ & \\
\hline $\begin{array}{l}\text { Non-farm self-employment }(1=\text { yes; } \\
0=\text { not })\end{array}$ & $8 \%$ & & $16 \%$ & & $26 \%$ & & $17 \%$ & \\
\hline Migration $(1=$ yes; $0=$ not $)$ & $10 \%$ & & $13 \%$ & & $15 \%$ & & $13 \%$ & \\
\hline Farmer association $(1=$ yes; $0=$ not $)$ & $41 \%$ & & $34 \%$ & & $29 \%$ & & $35 \%$ & \\
\hline Communist party $(1=$ yes; $0=$ not $)$ & $3 \%$ & & $7 \%$ & & $12 \%$ & & $7 \%$ & \\
\hline Annual cropland $\left(\mathrm{m}^{2}\right)$ & 4002 & 7408 & 2679 & 5556 & 3355 & 28,583 & 3345 & 17351 \\
\hline Perennial cropland $\left(\mathrm{m}^{2}\right)$ & 1223 & 4175 & 1502 & 6487 & 2321 & 12,869 & 1682 & 8674 \\
\hline Forestland $\left(\mathrm{m}^{2}\right)$ & 3391 & 27,057 & 1463 & 8500 & 1214 & 12,250 & 2023 & 17,862 \\
\hline Aquaculture land $\left(\mathrm{m}^{2}\right)$ & 265 & 2215 & 485 & 3199 & 673 & 6268 & 474 & 4262 \\
\hline Garden land $\left(\mathrm{m}^{2}\right)$ & 213 & 735 & 194 & 806 & 202 & 1111 & 203 & 899 \\
\hline
\end{tabular}

Source: authors' own calculation from the 2018 VHLSS. ${ }^{a}$ This ratio is calculated by the number of members aged under 15 and over 59 , divided by the number of members aged $15-59$.

\subsection{Impacts of Education on Household Income}

The impact of education on the log of monthly household income per capita is given in Table 3. Model 1 reports the impact of the number of formal schooling years, Model 2 shows the impact of highest qualification, while the impact of vocational education is reported in Model 3. In all models, the coefficients on education variables are highly statistically significant and positive. For instance, additional year of formal schooling would increase household income by about $4 \%$, holding all other factors constant in Model 1. In Model 2, the result indicates that income levels increase with higher level of qualification. Specifically, income per capita is about $16 \%$ higher for household with the head completing upper secondary school than that for those without formal education. Similar and larger effects are observed for those with professional secondary (39\%), college $(48 \%)$, and university $(51 \%)$ degrees. Substantial and positive effects are also found for households with vocational education. Per capita income is more likely to be approximately $30 \%, 22 \%$, and $23 \%$ higher for those with the head 
having vocational college, secondary apprentice, and primary vocational diplomas, respectively. Thus, our study confirms that education, measured by any indicators, has a positive effect on household income in rural Vietnam.

Table 3. The effect of education on household income.

\begin{tabular}{|c|c|c|c|c|c|c|}
\hline \multirow[t]{2}{*}{ Explanatory Variables } & \multicolumn{2}{|c|}{$\begin{array}{c}\text { Schooling Years } \\
\text { Model } 1\end{array}$} & \multicolumn{2}{|c|}{$\begin{array}{c}\text { Highest Degrees } \\
\text { Model } 2\end{array}$} & \multicolumn{2}{|c|}{$\begin{array}{c}\text { Vocational Education } \\
\text { Model } 3\end{array}$} \\
\hline & Coefficients & SE & Coefficients & SE & Coefficients & SE \\
\hline Ethnicity & $0.42 * * *$ & $(0.019)$ & $0.47^{* * *}$ & $(0.020)$ & $0.49^{* * *}$ & $(0.020)$ \\
\hline Age & $0.01^{* * *}$ & $(0.000)$ & $0.00^{* * *}$ & $(0.000)$ & $0.00^{* * *}$ & $(0.000)$ \\
\hline Marital status & $0.04^{* * *}$ & $(0.006)$ & $0.05^{* * *}$ & $(0.006)$ & $0.06^{* * *}$ & $(0.006)$ \\
\hline Gender & $-0.03 * *$ & $(0.012)$ & -0.00 & $(0.012)$ & -0.02 & $(0.012)$ \\
\hline Dependency ratio & $-0.54^{* * *}$ & $(0.013)$ & $-0.54^{* * *}$ & $(0.013)$ & $-0.55^{* * *}$ & $(0.013)$ \\
\hline Household size & $-0.04^{* * *}$ & $(0.003)$ & $-0.04^{* * *}$ & $(0.003)$ & $-0.04^{* * *}$ & $(0.003)$ \\
\hline Wage employment & $0.11^{* * *}$ & $(0.010)$ & $0.11 * * *$ & $(0.010)$ & $0.11^{* * *}$ & $(0.010)$ \\
\hline Non-farm self-employment & $0.29 * * *$ & $(0.011)$ & $0.32^{* * *}$ & $(0.012)$ & $0.31^{* * *}$ & $(0.012)$ \\
\hline Farmer association & $-0.06^{* * *}$ & $(0.010)$ & $-0.06^{* * *}$ & $(0.010)$ & $-0.07^{* * *}$ & $(0.010)$ \\
\hline Communist party & $0.18^{* * *}$ & $(0.013)$ & $0.18^{* * *}$ & $(0.014)$ & $0.34^{* * *}$ & $(0.013)$ \\
\hline Migration & $0.14^{* * *}$ & $(0.012)$ & $0.14^{* * *}$ & $(0.012)$ & $0.13^{* * *}$ & $(0.012)$ \\
\hline Schooling years & $0.04^{* * *}$ & $(0.001)$ & & & & \\
\hline Primary & & & $0.02^{* *}$ & $(0.010)$ & & \\
\hline Lower secondary & & & $0.10 * * *$ & $(0.010)$ & & \\
\hline Upper secondary & & & $0.16^{* * *}$ & $(0.015)$ & & \\
\hline Professional secondary & & & $0.39 * * *$ & $(0.022)$ & & \\
\hline College & & & $0.48^{* * *}$ & $(0.031)$ & & \\
\hline University and higher & & & $0.51^{* * *}$ & $(0.022)$ & & \\
\hline Primary vocational & & & & & $0.23^{* * *}$ & $(0.019)$ \\
\hline Secondary apprentice & & & & & $0.22 * * *$ & $(0.023)$ \\
\hline Vocational college & & & & & $0.29 * * *$ & $(0.062)$ \\
\hline Annual cropland & $-0.01^{* * *}$ & $(0.001)$ & $-0.01 * * *$ & $(0.001)$ & $-0.01 * * *$ & $(0.002)$ \\
\hline Perennial cropland & $0.01^{* * *}$ & $(0.002)$ & $0.01 * * *$ & $(0.002)$ & $0.01^{* * *}$ & $(0.002)$ \\
\hline Forestland & $-0.01^{* *}$ & $(0.002)$ & $-0.01^{* * *}$ & $(0.002)$ & $-0.01^{* * *}$ & $(0.002)$ \\
\hline Aquaculture land & $0.01 * * *$ & $(0.002)$ & $0.01 * * *$ & $(0.002)$ & $0.01 * * *$ & (0.003) \\
\hline Garden land & $-0.00^{* *}$ & $(0.002)$ & -0.00 & $(0.002)$ & -0.00 & $(0.002)$ \\
\hline Mekong Delta & -0.02 & $(0.018)$ & $-0.08^{* * *}$ & $(0.018)$ & $-0.11^{* * *}$ & $(0.018)$ \\
\hline Southeast & $0.11^{* * *}$ & $(0.023)$ & $0.08^{* * *}$ & $(0.024)$ & $0.05^{* *}$ & $(0.024)$ \\
\hline Central Highlands & $-0.20^{* * *}$ & $(0.028)$ & $-0.23^{* * *}$ & $(0.028)$ & $-0.23^{* * *}$ & $(0.029)$ \\
\hline South Central Coast & $-0.15^{* * *}$ & $(0.020)$ & $-0.19^{* * *}$ & $(0.020)$ & $-0.20 * * *$ & $(0.020)$ \\
\hline North Central Coast & $-0.25^{* * *}$ & $(0.021)$ & $-0.26^{* * *}$ & $(0.022)$ & $-0.26^{* * *}$ & $(0.022)$ \\
\hline West Northern Mountains & $-0.26^{* * *}$ & $(0.037)$ & $-0.27^{* * *}$ & $(0.038)$ & $-0.27^{* * *}$ & $(0.038)$ \\
\hline East Northern Mountains & $-0.15^{* * *}$ & $(0.023)$ & $-0.16^{* * *}$ & $(0.023)$ & $-0.16^{* * *}$ & $(0.023)$ \\
\hline Constant & $7.17^{* * *}$ & $(0.038)$ & $7.44^{* * *}$ & $(0.037)$ & $7.52^{* * *}$ & $(0.037)$ \\
\hline Observations & 29,709 & & 29,709 & & 29,709 & \\
\hline R-squared & 0.350 & & 0.336 & & 0.321 & \\
\hline
\end{tabular}

Note: Robust standard errors in parentheses. ${ }^{* * *} p<0.01,{ }^{* *} p<0.05,{ }^{*} p<0.1$; Source: authors' own calculation from the 2018 VHLSS.

Table 4 shows the effect of schooling years on various quantiles using a quantile regression analysis. The result confirms that there is large difference in the income effect of education across percentiles. Also, the result shows that an additional year of formal schooling brings higher income levels for those at higher income percentiles. For example, an additional year of formal schooling would increase the monthly per capita income by 47 thousand VND for those at the lowest quantile (10th). However, the effect tends to increase with higher quantiles, with about 124 thousand VND and 154 thousand VND for those at the 75th and the 90th quantile, respectively. This implies that education tends to benefit the better-off more than the poor. Thus, our study provides the fresh evidence that education, as measured by schooling years of household heads, increase income inequality in rural Vietnam. A similar effect is also found in South Asia, India, and Pakistan (Fasih et al. 2012). This can be explained by the fact that better-off households tend to have a higher endowment of unobservable ability and skills than do poorer households. (Sakellariou et al. 2006). Also, this suggests that for the same level of education, richer households tend to have better quality of education than do the poor. 
Table 4. Quantile effects of schooling years on household income.

\begin{tabular}{|c|c|c|c|c|c|}
\hline \multirow{2}{*}{ Explanatory Variables } & \multicolumn{5}{|c|}{ Quantile Regression } \\
\hline & $\begin{array}{l}\text { the 10th } \\
\text { Quantile }\end{array}$ & $\begin{array}{l}\text { the 25th } \\
\text { Quantile }\end{array}$ & $\begin{array}{l}\text { the 50th } \\
\text { Quantile }\end{array}$ & $\begin{array}{l}\text { the 75th } \\
\text { Quantile }\end{array}$ & $\begin{array}{l}\text { the 90th } \\
\text { Quantile }\end{array}$ \\
\hline Ethnicity & $\begin{array}{c}359.06^{* * *} \\
(17.144)\end{array}$ & $\begin{array}{c}530.35^{* * *} \\
(23.104)\end{array}$ & $\begin{array}{c}737.49 * * * \\
(30.346)\end{array}$ & $\begin{array}{c}995.82^{* * *} \\
(32.262)\end{array}$ & $\begin{array}{c}1290.71 * * * \\
(82.785)\end{array}$ \\
\hline Age & $\begin{array}{l}4.68^{* * *} \\
(0.482)\end{array}$ & $\begin{array}{l}8.03^{* * *} \\
(0.561)\end{array}$ & $\begin{array}{c}12.25^{* * *} \\
(0.607)\end{array}$ & $\begin{array}{c}15.25^{* * *} \\
(0.951)\end{array}$ & $\begin{array}{c}17.22 * * * \\
(1.916)\end{array}$ \\
\hline Marital status & $\begin{array}{c}115.68^{* * *} \\
(29.850)\end{array}$ & $\begin{array}{c}135.06^{* * *} \\
(27.799)\end{array}$ & $\begin{array}{c}157.34^{* * *} \\
(32.558)\end{array}$ & $\begin{array}{c}277.69 * * * \\
(52.802)\end{array}$ & $\begin{array}{c}317.31 * * * \\
(73.923)\end{array}$ \\
\hline Gender & $\begin{array}{l}-29.74 \\
(26.333)\end{array}$ & $\begin{array}{c}-34.41 \\
(29.358)\end{array}$ & $\begin{array}{c}-57.54 \\
(35.566)\end{array}$ & $\begin{array}{c}-115.47^{* *} \\
(49.310)\end{array}$ & $\begin{array}{c}-96.53 \\
(83.389)\end{array}$ \\
\hline Dependency ratio & $\begin{array}{c}-616.17^{* * *} \\
(24.834)\end{array}$ & $\begin{array}{c}-970.18^{* * *} \\
(32.113)\end{array}$ & $\begin{array}{c}-1347.36^{* * *} \\
(36.761)\end{array}$ & $\begin{array}{c}-1901.93^{* * *} \\
(55.051)\end{array}$ & $\begin{array}{c}-2386.51 \text { *** } \\
(78.918)\end{array}$ \\
\hline Household size & $\begin{array}{c}1.76 \\
(3.611)\end{array}$ & $\begin{array}{c}-26.62^{* * *} \\
(4.325)\end{array}$ & $\begin{array}{c}-69.77^{* * *} \\
(6.620)\end{array}$ & $\begin{array}{c}-164.23 * * * \\
(8.983)\end{array}$ & $\begin{array}{c}-272.05^{* * *} \\
(13.495)\end{array}$ \\
\hline Wage employment & $\begin{array}{c}225.30 * * * \\
(9.905)\end{array}$ & $\begin{array}{c}270.30^{* * *} \\
(15.917)\end{array}$ & $\begin{array}{c}266.18^{* * *} \\
(21.000)\end{array}$ & $\begin{array}{c}94.60^{* * *} \\
(27.033)\end{array}$ & $\begin{array}{c}-143.97^{* * *} \\
(44.147)\end{array}$ \\
\hline Nonfarm self-employment & $\begin{array}{c}350.69 * * * \\
(42.788)\end{array}$ & $\begin{array}{c}501.71 * * * \\
(27.266)\end{array}$ & $\begin{array}{c}720.81 * * * \\
(38.663)\end{array}$ & $\begin{array}{c}970.54 * * * \\
(53.690)\end{array}$ & $\begin{array}{c}1419.87^{* * *} \\
(118.706)\end{array}$ \\
\hline Migration & $\begin{array}{c}178.89 * * * \\
(26.828)\end{array}$ & $\begin{array}{c}246.04 * * * \\
(30.738)\end{array}$ & $\begin{array}{c}294.21 * * * \\
(31.671)\end{array}$ & $\begin{array}{c}377.39 * * * \\
(45.512)\end{array}$ & $\begin{array}{c}624.58^{* * *} \\
(75.536)\end{array}$ \\
\hline Schooling years & $\begin{array}{c}46.59 * * * \\
(2.357)\end{array}$ & $\begin{array}{c}66.74^{* * *} \\
(2.158)\end{array}$ & $\begin{array}{c}90.97^{* * *} \\
(3.116)\end{array}$ & $\begin{array}{c}121.56^{* * *} \\
(4.471)\end{array}$ & $\begin{array}{c}154.15^{* * *} \\
(6.199)\end{array}$ \\
\hline Annual cropland & $\begin{array}{c}-14.63^{* * *} \\
(2.243)\end{array}$ & $\begin{array}{c}-22.99 * * * \\
(2.181)\end{array}$ & $\begin{array}{c}-27.41^{* * *} \\
(3.351)\end{array}$ & $\begin{array}{c}-34.47^{* * *} \\
(5.249)\end{array}$ & $\begin{array}{c}-38.08^{* * *} \\
(9.399)\end{array}$ \\
\hline Perennial cropland & $\begin{array}{l}3.28 * * \\
(1.299)\end{array}$ & $\begin{array}{l}5.77^{* * *} \\
(2.119)\end{array}$ & $\begin{array}{c}11.92 * * * \\
(2.951)\end{array}$ & $\begin{array}{c}30.63^{* * *} \\
(4.318)\end{array}$ & $\begin{array}{c}59.85^{* * *} \\
(9.946)\end{array}$ \\
\hline Forestland & $\begin{array}{c}-5.79 * * * \\
(1.796)\end{array}$ & $\begin{array}{c}-7.82 * * * \\
(1.661)\end{array}$ & $\begin{array}{c}-9.60 * * * \\
(2.395)\end{array}$ & $\begin{array}{c}-12.41^{* * *} \\
(3.737)\end{array}$ & $\begin{array}{l}-4.35 \\
(5.006)\end{array}$ \\
\hline Aquaculture land & $\begin{array}{c}10.99 * * * \\
(2.624)\end{array}$ & $\begin{array}{c}12.13^{* * *} \\
(4.629)\end{array}$ & $\begin{array}{c}13.93 * * \\
(5.518)\end{array}$ & $\begin{array}{c}42.18^{* * *} \\
(9.090)\end{array}$ & $\begin{array}{l}83.01 * * * \\
(13.995)\end{array}$ \\
\hline Garden land & $\begin{array}{l}-5.28^{*} \\
(3.079)\end{array}$ & $\begin{array}{c}-8.46^{* *} \\
(3.464)\end{array}$ & $\begin{array}{c}-11.54^{* * *} \\
(3.773)\end{array}$ & $\begin{array}{c}-8.11 \\
(5.256)\end{array}$ & $\begin{array}{l}-20.05^{*} \\
(10.356)\end{array}$ \\
\hline Farmer association & $\begin{array}{c}-103.70 * * * \\
(16.024)\end{array}$ & $\begin{array}{c}-130.93^{* * *} \\
(14.443)\end{array}$ & $\begin{array}{c}-163.23^{* * *} \\
(18.871)\end{array}$ & $\begin{array}{c}-193.50 * * * \\
(33.859)\end{array}$ & $\begin{array}{c}-225.33^{* * *} \\
(44.813)\end{array}$ \\
\hline Party member & $\begin{array}{c}287.31 * * * \\
(41.182)\end{array}$ & $\begin{array}{c}407.87^{* * *} \\
(33.243)\end{array}$ & $\begin{array}{c}483.62 * * * \\
(50.378)\end{array}$ & $\begin{array}{c}673.63^{* * *} \\
(85.196)\end{array}$ & $\begin{array}{c}931.11^{* * *} \\
(87.088)\end{array}$ \\
\hline Region (included) & & & & & \\
\hline Constant & $\begin{array}{c}663.43^{* * *} \\
(53.278)\end{array}$ & $\begin{array}{c}1022.77^{* * *} \\
(54.693)\end{array}$ & $\begin{array}{c}1520.22 * * * \\
(82.635)\end{array}$ & $\begin{array}{c}2471.05^{* * *} \\
(114.184)\end{array}$ & $\begin{array}{c}3697.45^{* * *} \\
(232.253)\end{array}$ \\
\hline Observations & 29,709 & 29,709 & 29,709 & 29,709 & 29,709 \\
\hline Pseudo R2 & 0.12 & 0.16 & 0.17 & 0.17 & 0.17 \\
\hline
\end{tabular}

We also found that a number of household characteristics have a significant effect on household income. Similar to previous findings in Vietnam (Nguyen and Tran 2018; Tran and Vu 2018), our research results confirm that larger households and higher dependency ration tend to reduce household income (Table 3). However, the results in Table 4 show that these negative effects tend to be higher for richer households. Households with the head belonging to the Kinh/Hoa population also earn income level that is higher (about $42 \%$, Model 1, Table 3) than do those with the head being the ethnic minority group. However, Table 4 shows that this income gap tend to increase with higher quantiles, suggesting that ethnicity increase income inequality.

The OLS estimates in Table 3 confirm that on average, wage and confirmed self-employment are found to increase the household income. Specifically, households with wage or nonfarm self-employment would earn an income level that is about $11 \%$ and $30 \%$ higher than those without wage or nonfarm self-employment, respectively. Notably, the estimates from quantile regression in Table 4 reveals that the income effect of wage employment tend to decrease with income quantiles while that of nonfarm self-employment tends to increase with income quantiles. This suggests that 
wage employment has a reducing effect on income inequality while nonfarm self-employment has an increasing effect on inequality.

Migration is found to have a positive effect on household income for households at all quantile considered but the effect increases with higher quantiles. Households with a party communist membership tend to have higher income levels than those without this membership and the effect is larger for richer households. Nevertheless, households with a farmer association membership tend to earn lower income than those without. Interestingly, the study found that income is negatively associated with annual cropland and forestland, whereas it is positively linked with perennial cropland and aquaculture land. This suggests that different lands play different roles in household income in rural Vietnam. Our findings are partly in line with previous findings in some developing countries where having more cropland tend to reduce household income (Tuyen 2014).

\section{Conclusions and Policy Recommendations}

This study investigated the effect of household income in rural Vietnam using both mean and quantile regression approach, which allows parameters to vary across income groups. Cross-section data from 29,710 rural households across six regions were used. Our quantitative analysis confirms that the education of household head, measured by any indicator, has a positive effect on household income. Notably, our research results show that estimates for conditional mean regression with OLS could be misleading. While most of the parameters estimated from the OLS maintained their signs, their magnitudes vary depending on the quantile being considered. We provide the fresh evidence that an additional year of formal schooling tends to bring higher income for those at higher income levels. This suggests that education increases inequality in rural Vietnam. As already explained, the higher impact of education for richer households might stem the fact that richer households have better quality of education or higher levels of ability or skills that are unobservable in the model.

Notably, our study shows that not all types of production land are positively associated with household income in rural Vietnam. This supports the argument by Rigg (2006) that the role of cropland in shaping rural livelihoods have been gradually replaced by education and nonfarm activities in many developing countries. This suggests that redistribution or improving the access of rural households to land should not be seen as a major approach of improving household welfare in Vietnam. Our results show that poorer households tend to have lower levels of education in rural Vietnam. A policy implication here is that increasing the access of the poor to better education is expected to help them improve their income and reduce inequality in rural Vietnam. Finally, the positive effect of nonfarm employment in our research also implies that promoting opportunities for rural household to participate in nonfarm activities should be practically of use because nonfarm employment was found to be a major factor contributing to household income.

Funding: This research is funded by The Vietnamese Ministry of Education and Training under project number B2019-TMA-09.

Conflicts of Interest: The author declares no conflict of interest.

\section{References}

Alves, Nuno. 2012. The impact of education on household income and expenditure inequality. Applied Economics Letters 19: 915-19. [CrossRef]

Doan, Tinh, Quan Le, and Tuyen Quang Tran. 2018a. Lost in Transition? Declining Returns to Education in Vietnam. The European Journal of Development Research 30: 195-216. [CrossRef]

Doan, Tinh, Tran Quang Tuyen, and Hien Nguyen. 2018b. Local competitiveness and labour market retursn in Vietnam. Hitotsubashi Journal of Economics 59: 1-23.

Fasih, Tazeen, Geeta Kingdon, Harry Anthony Patrinos, Chris Sakellariou, and Mans Soderbom. 2012. Heterogeneous Returns to Education in the Labor Market. Washington: The World Bank.

Koenker, Roger. 2005. Quantile Regression. Cambridge: Cambridge University Press. 
Koenker, Roger, and Kevin F. Hallock. 2001. Quantile regression. Journal of Economic Perspectives 15: 143-56. [CrossRef]

Lingxin, Hao, and Naiman Q. Daniel. 2007. Quantile Regression. Thousand Oaks: Sage.

Tien, Nguyen Dung. 2014. An Analysis of Labour Market Returns to Education in Vietnam: Evidence from the National Labour Force Survey 2012. International Training Centre of the International Labour Organization Working Paper. Turin: International Training Centre of the International Labour Organization.

Nguyen, Thanh Viet, and Tuyen Quang Tran. 2018. Forestland and rural household livelihoods in the North Central Provinces, Vietnam. Land Use Policy 79: 1-13. [CrossRef]

Pede, Valerien O., Joyce S. Luis, Thelma R. Paris, and Justin D. McKinley. 2012. Determinants of household income: A quantile regression approach for four rice-producing areas in the Philippines. Asian Journal of Agriculture and Development 9: 65-76.

Revenga, Ana, Carlos Silva-Jauregui, Lucia Haulikova, Thesia Garner, Anton Marcincin, Dena Ringold, Manuel De la Rocha, Carolina Sanchez-Paramo, Helen Shahriari, and Diane Steele. 2002. Slovak Republic: Living Standards, Employment, and Labor Market Study. Washington: The World Bank.

Rigg, J. 2006. Land, farming, livelihoods, and poverty: Rethinking the links in the rural South. World Development 34: 180-202. [CrossRef]

Sakellariou, C., H. A. Patrinos, and Ridao-C. Cano. 2006. Estimating the Returns to Education: Accounting for Heterogeneity in Ability. World Bank Policy Research Working Paper 4040. Washington: The World Bank, Available online: http://documents.worldbank.org/curated/en/493861468046772160/pdf/wps4040.pdf (accessed on 15 October 2019).

Tuyen, Quang Tran. 2014. A review on the link between nonfarm employment, land and rural livelihoods in developing countries and Vietnam. Ekonomski Horizonti 16: 113-23. [CrossRef]

Tran, Quang Tuyen, and Van Huong Vu. 2018. Chất lượng quản trị công cấp tỉnh và mức sống dân cư: bằng chứng mới từ dữ liệu khảo sát mức sống dân cứ 2016. Kinh tế và Phát triển, Số tháng 3: 1-13.

Tran, Tai Anh, Tuyen Quang Tran, and Hai Thi Nguyen. 2018. The role of education in the livelihood of households in the Northwest region, Vietnam. Educational Research for Policy and Practice, 1-15. [CrossRef]

Tran, Tuyen Quang, Hiep Hung Pham, Hoa Thi Vo, Hong Thuy Luu, and Huong Mai Nguyen. 2019. Local governance, education and occupation-education mismatch: Heterogeneous effects on wages in a lower middle income economy. International Journal of Educational Development 71: 102101. [CrossRef]

(C) 2020 by the author. Licensee MDPI, Basel, Switzerland. This article is an open access article distributed under the terms and conditions of the Creative Commons Attribution (CC BY) license (http://creativecommons.org/licenses/by/4.0/). 